\title{
PERTANGGUNGJAWABAN HUKUM TERHADAP KEDUDUKAN AKTA OTENTIK YANG DIBUAT SELAMA MASA CUTI (PUTUSAN NOMOR : 1/PTS/Mj.PWN.DKIJakarta/xi/2017)
}

\author{
Stefani Christanti Hamdani
}

(Mahasiswi Program S1 Fakultas Hukum Universitas Tarumanagara)

(E-mail: stefanihamdanii@gmail.com)

\section{Endang Pandamdari}

(Corresponding Author)

(Dosen Fakultas Hukum Universitas Tarumanagara, Meraih Gelar Sarjana Hukum dari Fakultas Hukum Universitas Indonesia, Magister Hukum dari Fakultas Hukum Universitas Indonesia)

(E-mail: epandamdari@yahoo.com)

\begin{abstract}
Notary is a profession that is very required in the field of law. In these case, notary acts as a public official in providing a legal services to the society. Notary has a several function like establishment a company, making a deed, legalizing documents, waarmerking, and other services. But in a reality, there are many notaries still do not meet the applicable terms and conditions, "How Is The Notary's Responsibility Towards Authentic Deed Position During The Leave" this is the main problem we will disscused in this report. The research method used is a descriptive normative research method, which is based on primary data and secondary data as other supporting data which are analyzed qualitatively. From the results of the study explained that that Drs. Andika, as the reporter, came to the reported office named Netty Maria Machdar with the intention to make a certificate of borrowing and guarantee with a certificate, but by Netty's mother a letter of authorization to sell was made which resulted in a loss. In the Letter Number 04 / Ket.Cuti-MPPN / II / 2015 said that it turned out that Notary Netty Maria Machdar was on leave after knowing the deeds and leave certificate. the notary who made the deed during the leave was found quilty, and the position of the deed was a deed under the hand. Which means the notary who made the deed during the leave was found quilty, and the position of the deed was a deed under the hand.
\end{abstract}

Keywords : Authentic Deed, Leave Notary, Notary Responsibility 


\section{PENDAHULUAN}

\section{A. Latar Belakang}

Negara Kesatuan Republik Indonesia (NKRI) mempunyai dasar negara yaitu Pancasila serta Undang-Undang Dasar Negara Republik Indonesia Tahun 1945 sebagai batang tubuh yang menjadikan Indonesia sebagai negara hukum. Hukum yang berlaku di suatu negara merupakan perlindungan kepentingan manusia sehingga hukum mengatur segala hubungan antar Individu atau perorangan. ${ }^{1}$ Sehingga manusia atau mahluk sosial akan selalu berhubungan dengan manusia lain nya. Hal ini terjadi karena adanya interaksi yang terjalin diantara manusia yang satu dengan manusia lainnya tersebut tidak hanya berdimensi kemanusiaan dan sosial budaya, namun juga menyangkut aspek hukum, termasuk perdata.

Pada Undang-Undang Nomor 2 Tahun 2014 tentang Perubahan Atas Undang-Undang Nomor 30 Tahun 2004 tentang Jabatan Notaris menyatakan bahwa: "Negara Republik Indonesia sebagai negara hukum berdasarkan Pancasila dan Undang-Undang Dasar Negara Republik Indonesia Tahun 1945 menjamin kepastian, ketertiban, dan Perlindungan Hukum bagi setiap warga negara". Segala hal yang dilakukan oleh setiap individu yang merupakan bagian dari suatu masyarakat sosial tidak akan pernah lepas dari tanggung jawab.

Untuk menjamin kepastian, ketertiban dan perlindungan hukum dibutuhkan alat bukti tertulis yang bersifat otentik mengenai pernbuatan, perjanjian, penetapan, dan peristiwa hukum yang dibuat di hadapan atau oleh pejabat yang berwenang. Dalam hal ini pejabat yang berwenang adalah notaris sebagai pejabat umum yang menjalankan profesi dalam memberikan jasa hukum kepada masyarakat, perlu mendapatkan perlindungan dan jaminan demi tercapainya kepastian hukum. ${ }^{2}$ Notaris merupakan jabatan berwajah ganda, di satu pihak ia pemangku jabatan negara di pihak lain ia pelaksana profesi.

\footnotetext{
1) Mochtar Kusumaatmaja, B. Arief Sidharta, Pengantar Ilmu Hukum Suatu Pengenalan Pertama Ruang Lingkup Berlakunya Ilmu Hukum Buku I, (Bandung: Alumni, 2000), hal. 17.

${ }^{2)}$ Indonesia, Undang-Undang Nomor 2 Tahun 2014 tentang Jabatan Notaris, hal. 1.
} 
Namun dasarnya sama ialah mengatur hubungan hukum secara tertulis antara berbagai pihak. Dan pelaksanaannya atas dasar permintaan pihak-pihak yang berkepentingan, bila mereka menginginkan penyelesaian secara baik-baik (damai). ${ }^{3}$

Di Indonesia kebutuhan akan Notaris dan PPAT tidak dapat terelakkan. Dalam hal ini, kebutuhan tersebut dapat bervariasi mulai dari pendirian PT, membuat akta, legalisasi dokumen, waarmerking dan jasa lain. Tidak hanya dalam dunia bisnis tetapi juga untuk kebutuhan yang bersifat pribadi seperti membuat akta waris, akta hibah, balik nama sertifikat, pengecekan sertifikat tanah serta lainnya. ${ }^{4}$ Sehingga Notaris dan PPAT tidak dapat dipisahkan karena diperlukan bagi masyarakat di Indonesia.

Menurut Undang-Undang Nomor 2 Tahun 2014 tentang Perubahan Atas Undang-Undang Nomor 30 Tahun 2004 tentang Jabatan Notaris pada Pasal 1 Angka 1 menentukan bahwa: "Notaris adalah pejabat umum yang berwenang untuk membuat akta otentik dan memiliki kewenangan lainnya sebagaimana yang dimaksud dalam Undang-Undang ini atau berdasarkan Undang-Undang lainnya". Mengenai Pejabat umum diartikan sebagai pejabat yang diserahi tugas untuk membuat akta otentik yang melayani kepentingan publik, dan kualifikasi seperti itu diberikan kepada notaris. ${ }^{5}$

Berdasarkan ketentuan di atas notaris adalah pejabat umum yang punya kewenangan untuk membuat akta otentik mengenai semua perbuatan perjanjuan dan ketetapan yang diharuskan oleh peraturan perundang dan/atau yang dikehendaki oleh yang berkepentingan, selama pembuatan akta tersebut tidak dikhususkan bagi pejabat umum lainnya. Pemberian wewenang, kepada pejabat atau instansi lain, seperti kantor Catatan Sipil, tidak berarti memberikan kualifikasi sebagai pejabat umum tapi hanya menjalankan fungsi

\footnotetext{
3) Notaris Soetardjo Soemoatmodjo, Apakah: Notaris, Pejabat Pembuat Akta Tanah dan Pejabat Lelang, (Yogyakarta: Liberty, 1986), hal. 5.

4) Leo Faraytody, "Memahami Pentingnya Jasa Notaris Dan PPAT Dalam Bisnis", https://easybiz.id/memahami-pentingnya-jasa-notaris-dan-ppat-dalam-bisnis/, 2018

5) Habib Adjie, Sekilas Dunia Notaris \& PPAT Indonesia (Kumpulan Tulisan), (Bandung: Mandar Maju, 2009), hal. 16.
} 
sebagai pejabat umum saja ketika membuat akta-akta yang ditentukan oleh aturan hukum, dan kedudukan mereka tetap dalam jabatannya semula sebagai Pegawai Negeri. ${ }^{6}$

Pada Undang-Undang Nomor 2 Tahun 2014 tentang Jabatan Notaris Pasal 15 Angka 1 juga dinyatakan bahwa "Notaris berwenang membuat akta otentik mengenai semua perbuatan, perjanjian, dan penetapan yang diharuskan oleh peraturan perundang-undnagan dan/atau yang dikehendaki oleh yang berkepentingan untuk dinyatakan dalam Akta autentik, menjamin kepastian tanggal pembuatan Akta, menyimpan Akta, memberikan grosse, salinan dan kutipan Akta, semua itu sepanjang pembuatan Akta itu tidak juga ditugaskan atau dikecualikan kepada pejabat lain atau orang lain yang ditetapkan oleh Undang-Undang". 7

Dalam Peraturan Pemerintah Republik Indonesia Nomor 24 Tahun 2016 tentang Perubahan Peraturan Pemerintah Nomor 37 Tahun 1998 tentang Peraturan Jabatan Pejabat Pembuatan Akta Tanah pada Pasal 1 menentukan bahwa " PPAT adalah pejabat umum yang diberi kewenangan untuk membuat akta-akta otentik mengenai perbuatan hukum tertentu mengenai hak atas tanah atau Hak Milik Atas Satuan Rumah Susun”. Pada Pasal 7 Peraturan Pemerintah Republik Indonesia Nomor 24 Tahun 2016 dinyatakan bahwa "PPAT dapat merangkap jabatan sebagai notaris di tempat kedudukan notaris". 8

Oleh karena itu akta otentik yang dibuat oleh notaris hanya karena kepentingan peraturan perundang-undangan tetapi juga untuk kepentingan para pihak lain yang berkepentingan untuk memastikan hak dan kewajiban para pihak demi adanya kepastian, serta menghindari terjadinya sengketa antara kedua belah pihak. Pada Undang-Undang Nomor 2 Tahun 2014 Tentang Jabatan Notaris Pasal 16 Ayat (1) a mengatakan bahwa "pejabat notaris wajib bertindak amanah, jujur, saksama, mandiri, tidak berpihak, dan menjaga

\footnotetext{
6) Ibid, hal. 17.

7) Indonesia, Undang-undang Nomor 2 Tahun 2014 tentang Jabatan Notaris, Pasal 15.

8) Indonesia, Peraturan Pemerintah Republik Indonesia Nomor 24 Tahun 2016 tentang Perubahan Peraturan Pemerintah Nomor 37 Tahun 1998 tentang Peraturan Jabatan Pejabat Pembuatan Akta Tanah, Pasal 1.
} 
kepentingan pihak yang terkait dalam perbuatan hukum". ${ }^{9}$ Sehingga etika hukum bagi masyarakat yang telah mempercayainya untuk membuat akta otentik sebagai alat bukti terkuat bagi penyelesaian perkara secara murah dan cepat.

Dalam Undang-Undang Nomor 2 Tahun 2014 tentang Jabatan Notaris pada Pasal 1 Angka 3 dinyatakan bahwa "Notaris Pengganti adalah seorang yang untuk sementara menjabat sebagai notaris untuk menggantikan notaris yang sedang cuti, sakit, atau untuk sementara berhalangan menjalankan jabatannya sebagai notaris”. ${ }^{10}$ Dalam Pasal 33 Undang-Undang Nomor 2 Tahun 2014 tentang Jabatan Notaris adanya ketentuan sebagai syarat untuk menjadi notaris pengganti yang dinyatakan sebagai berikut: "Syarat untuk dapat diangkat menjadi Notaris Pengganti dan Pejabat Sementara Notaris adalah warga negara Indonesia yang berijazah sarjana hukum dan telah bekerja sebagai karyawan kantor Notaris paling sedikit 2 (dua) tahun bertutut-turut". ${ }^{11}$

Ada beberapa notaris yang menggunakan hak cutinya sehingga notaris harus segara menunjuk notaris pengganti sebagai syarat agar notaris yang bersangkutan dapat mengambil hak cutinya. Dalam kasus ini banyaknya notaris yang sedang cuti tetapi masih dapat mengeluarkan akta autentik padahal sudah ada notaris pengganti. Padahal telah diataurnya ketentuan pada Pasal 36 Angka 3 dan Pasal 32 Angka 4 Peraturan Menteri Hukum dan Hak Asasi Manusia Republik Indonesia Nomor M.01.HT.03.01 Tahun 2006 tentang Syarat dan Tata Cara Pengangkatan, Perpindahan, dan Pemberhentian Notaris maka notaris wajib mengajukan cuti untuk jangka wakyu yang bersangkutan memangku jabatan sebagai pejabat negara dan akan diberhentikan sementara dari jabatannya, dan protokolnya akan diserahkan kepada notaris lain, Notaris yang menerima protokol tersebut wajib menyerahkan kembali kepada notaris yang telah menyelesaikannya tugasnya sebagai pejabat negara. ${ }^{12}$

\footnotetext{
9) Indonesia, Undang-undang Nomor 2 Tahun 2014 tentang Jabatan Notaris, Pasal 16

${ }^{10)}$ Indonesia, Undang-undang Nomor 2 Tahun 2014 tentang Jabatan Notaris, Pasal 1

11) Indonesia, Undang-undang Nomor 2 Tahun 2014 tentang Jabatan Notaris, Pasal 33

12) Ibid., hal. 105.
} 
Kode Etik Notaris dirumuskan sebagai keseluruhan kaidah morah yang ditentukan oleh Perkumpulan Ikatan Notaris Indonesia (INI). Kode Etik berlaku dan diberlakukan bagi setiap dan semua anggota perkumpulan wajib ditaati dalam menjalankan tugas jabatan sebagai notaris. Setipa pemegang dan pelaku tugas jabatan notaris sebagi anggota perkumpulan juga terikat pada disiplin organisasi, yaitu kepatuhan anggota perkumpulan dalam rangka memenuhi kewajiban-kewajiban terutama kewajiban administrasi dan kewajiban finansial yang diatur oleh perkumpulan. ${ }^{13}$

Seorang notaris sangat perlu untuk mengetahui dan memehami kode etik,dimana mengatur perbuatan-perbuatan yang apabila di langgar maka akan mendapatkan sanki yang dijatuhkan. Untuk menegakkan kode etik dibentuk dewan kehormatan yang merupakan alat perlengkapan perkumpulan sebagai suatu badan atau lembaga mandiri dan bebas dari kepihakan dalam perkumpulan. Hubungan profesi Notaris dengan organisasi Notaris diatur kode etik Notaris, dimana keberadaan kode etik Notaris merupakan konsekuensi dari suatu pekerjaan terkait pelanggaran perilaku para Notaris yang hanya sampai pada sanksi moral. Kode etik Notaris ini memuat unsur kewajiban, larangan, pengecualian dan sanksi yang akan dijatuhkan apabila terbukti Notaris melanggar kode etik. Selain itu kode etik juga mengatur tata cara penegakkan kode etik dan pemecatan sementara sebagai anggota INI. ${ }^{14}$

Pada Pasal 32 Undang-Undang Nomor 2 Tahun 2014 tentang Jabatan Notaris dinyatakan bahwa ${ }^{15}$ :

1. Notaris yang menjalankan cuti wajib menyerahkan Protokol Notaris kepada Notaris Pengganti.

2. Notaris Pengganti menyerahkan kembali Protokol Notaris setelah cuti berakhir.

13) Jimly Asshiddiqie, Peradilan Etik dan Etika Konstitusi Perspektif Baru Tentang ('Rule of Law and Rule of Ethics' \& Constitutional Law and Constitutional Ethics') edisi revisi, (Jakarta: Sinar Grafika, 2016), hal. 181.

${ }^{14)}$ Pengurus Pusat Ikatan Notaris Indonesia, Jati Diri Notaris Indonesia, Dulu, Sekarang dan di Masa Datang, (Jakarta: PT Gramedia Pustaka, 2008), hal. 16.

15) Indonesia, Undang-undang Nomor 2 Tahun 2014 tentang Jabatan Notaris, Pasal 32. 
3. Serah terima sebagaimana dimaksud pada ayat (1) dan ayat (2) dibuatkan berita acara dan disampaikan kepada Majelis Pengawas Wilayah.

4. Notaris yang melanggar ketentuan sebagaimana dimaksud pada ayat (1), ayat (2), dan ayat (3) dapat dikenai sanksi berupa:

a. Peringatan tertulis;

b. Pemberhentian sementara;

c. Pemberhentian dengan hormat; atau

d. Pemberhentian dengan tidak hormat.

Dalam kasus yang penulis angkat dinyatakan bahwa adanya pejabat notaris yang melanggar kode etik, hal ini terjadi pada saat Pelapor yang bernama Andhika mendatangi kantor notaris Netty Maria Machdar dengan maksud untuk dibuatkan akta pinjam meminjam dengan jaminan sertifikat akan tetapi oleh Ibu Netty Maria Machdar dibuatkan surat kuasa menjual sehingga mengakibatkan kerugian pada Andhika. Permasalahan muncul akibat akta yang dibuat oleh Ibu Netty Maria Machdar tidak sesuai dengan keinginan Andhika dan baru diketahui notaris tersebut dalam keadaan cuti selama 1 (satu) tahun 6 (enam) bulan terhitung dari tanggal 02 Maret 2015 sampai dengan 02 September 2015. Setelah itu juga diketahui bahwa Ibu Netty Maria Machdar telah membuat akta notaris atas namanya sendiri sebanyak 146 (seratus empat puluh enam nomor).

Berdasarkan uraian diatas, diangkatlah judul penulisan ini "Pertanggungjawaban Hukum Terhadap Kedudukan Akta Otentik yang dibuat Selama Masa Cuti (Putusan Nomor: 1/PTS/Mj. PWN. Prov. DKIJakarta/XI/2017)

\section{B. Permasalahan}

Bagaimanakah tanggung jawab notaris terhadap kedudukan akta otentik yang dibuat selama masa cuti (Putusan Nomor: 1/PTS/Mj. PWN. Prov. DKIJakarta/xi/2017) ?" 


\section{Metode Penelitiaan}

\section{Jenis Penelitiaan}

Jenis penelitian yang digunakan dalam penelitian ini adalah penelitian hukum normatif, Menurut Peter Mahmud Marzuki bahwa pengertian penelitian hukum normatf adalah suatu proses untuk menemukan doktrindoktrin hukum guna menjawab isu hukum yang dihadapi. ${ }^{16}$ Penelitian hukum normatif selalu mengambil isu dari hukum sebagai sistem norma yang digunakan untuk "justifikasi" preskriptif tentang suatu peristiwa hukum. ${ }^{17}$ Penelitian hukum (legal research) adalah menemukan kebenaran koherensi, yaitu adakah aturan hukum sesuai dengan prinsip hukum, serta apakah tindakan seseorang sesuai dengan norma hukum atau prinsip hukum. ${ }^{18}$

\section{Jenis dan Teknik Pengumpulan Data}

Sumber-sumber penelitian hukum dapat dibedakan menjadi sumbersumber hukum yang berupa:

\section{a. Bahan Hukum Primer}

Bahan Hukum Primer yaitu bahan hukum yang bersifat autoritatif artinya mempunyai otoritas, yang terdiri dari:

1) Kitab Undang-Undang Hukum Perdata

2) Undang-Undang Nomor 2 Tahun 2014 tentang Perubahan UndangUndang Nomor 30 Tahun 2004 tentang Jabatan Notaris

3) Peraturan Menteri Hukum dan Hak Asasi Manusia Republik Indonesia Nomor 27 Tahun 20016 tentang Formasi Jabatan Notaris dan Penentuan Kategori Daerah

4) Peraturan Pemerintah Nomor 24 Tahun 2016 tentang Perubahan Atas Peraturan Pemerintah Nomor 37 Tahun 1998 tentang Peraturan Jabatan Pejabat Pembuat Tanah

\footnotetext{
16) Peter Mahmud Marzuki, Penelitian Hukum, Cetakan ke-11, (Jakarta: Kencana, 2011), hal. 35.

17) Mukti Fajar dan Yulianto Achmad, Dualisme Penelitian Hukum Normatif dan Empiris, (Yogyakarta: Pustaka Pelaja, 2010), hal. 36.

18) Peter Mahmud Marzuki, Penelitian Hukum Edisi Revisi, (Jakarta: Kencana Preneda Media Group, 2013), hal. 47.
} 
b. Bahan Hukum Sekunder

Bahan Hukum Sekunder berupa semua publikasi tentang hukum yang bukan merupakan dokumen-dokumen resmi, publikasi tentang hukum antara lain ${ }^{19}$ Buku-buku teks, Kamus-kamus hukum, Jurnal-jurnal hukum, Komentar-komentar atas putusan pengadilan.

c. Bahan Non Hukum ${ }^{20}$ :

1) Laporan-laporan penelitian non-hukum

2) Jurnal-jurnal non-hukum sepanjang masih relevan

3) Kamus Besar Bahasa Indonesia.

\section{Pendekatan Penelitian}

Pada pendekatan penelitian ini, menggunakan pendekatan UndangUndang dan studi kasus. Pendekatan Undang-Undang adalah pendekatan yang dilakukan dengan menelaah semua Undang-Undang dan regulasi yang bersangkutan paut dengan isu hukum yang sedang ditangani. Pendekatan undang-undang ini membuka kesempatan bagi peneliti untuk mempelajari adakah konsistensi dan kesesuaian antara suatu UndangUndang dan Undang-Undang Dasar atau antara regulasi dan UndangUndang. Hasil dari telaah tersebut merupakan suatu argumen untuk memecahkan isu yang dihadapi. ${ }^{21}$

Pendekatan Undang-Undang ini perlu memahami mengenai Jabatan Notaris serta doktrin yang mengacu pada isu hukum yang ditelaah. Studi kasus merupakan suatu studi terhadap kasus tertentu dari berbagai aspek hukum. $^{22}$

\section{Sifat Penelitian}

Dalam penelitian ini yang digunakan dalam penulisan ini adalah dengan studi pustaka terhadap bahan-bahan hukum normatif, baik bahan hukum primer, bahan hukum sekunder dan bahan non-hukum. Penelusuran

\footnotetext{
19) Peter Mahmud Marzuki, Op.Cit, hal. 141-142.

20) Ibid., hal. 143

21) Ibid., hal. 93.

22) Ibid., hal. 134.
} 
bahan-bahan hukum tersebut dapat dilakukan dengan membaca, melihat, mendengarkan, maupun melalui media internet. ${ }^{23}$

Setelah data dan bahan hukum dikumpulkan, tahap selanjutnya adalah melakukan pengolahan data, yaitu mengelola data sedemikian rupa sehingga data dan bahan hukum tersebut tersusun secara runtut dan sistematis. ${ }^{24}$ Pada penelitian hukum normatif, pengelolaan bahan bertujuan untuk mengadakan sistematis terhadap bahan-bahan hukum tertulis dengan cara melakukan seleksi data sekunder dan bahan hukum, kemudian melakukan klarifikasi menurut penggolongan bahan hukum dan menyusun data hasil penelitian tersebut secara sistematis dan logis. ${ }^{25}$

\section{Teknik Analisis Data}

Hasil pengelolahaan data pada hakekatnya merupakan kegiatan untuk mengadakan analisa terhadap permasalahan yang akan diteliti. Analisis data yang digunakan yaitu analisis kualitatif, yaitu dengan mengumpulkan data, mengkualifikasikan dan diinterpretasikan kemudian menghubungkan teori yang berhubungan dengan masalah dan akhirnya menarik kesimpulan untuk memperoleh suatu kesimpulan secara deduktif untuk menjawab pokok bahasan yang dibahas dalam karya ilmiah ini.

\section{PEMBAHASAN}

\section{A. Kronologi}

Pada Putusan Nomor : 1/PTS/Mj.PWN.Prov.DKIJakarta/xi/2017 merupakan putusan akibat notaris yang membuat akta otentik selama masa cuti. Hal ini terjadi pada saat Drs. Andika selaku pelapor mendatangi kantor terlapor yang bernama Netty Maria Machdar dengan maksud untuk dibuatkan akta pinjam meminjam dengan jaminan sertifikat akan tetapi oleh ibu Netty dibuatkan surat kuasa menjual sehingga mengakibatkan kerugian.

\footnotetext{
23) Mukti Fajar ND dan Yulianto Achmad, Op. Cit., hal.160.

24) Peter Mahmud Marzuki, Penelitian Hukum Edisi Revisi, (Jakarta: Kencana Preneda Media Group, 2013), hal. 180.

25) Ibid., hal.181.
} 
Drs. Andika menjelaskan untuk mengeksekusi rumah di Depok membutuhkan uang tunai sebesar Rp 500.000.000,- (lima ratus juta rupiah) yang disanggupi oleh David dengan bunga 4\% selama 3 (tiga) bulan dan diskonto 4\% dibayar dimuka dengan jaminan Sertifikat Hak Milik Nomor 11136 Kecamatan Beji Kota Depok. Drs. Andika menjelaskan setuju untuk menyerahkan sertifikat sedangkan uang pinjaman belum diterima belum diterima oleh Andika.

David mengubah jumlah pinjaman yang dijanjikan menjadi sebesar Rp 400.000.000,- (empat ratus juta rupiah) dan Drs. Andika meminta sebesar Rp 25.000.000,- (dua puluh lima juta rupiah) untuk keperluan membayar bunga pada bank dimana peminjaman akan jatuh tempo, tetapi keesokan harinya David hanya memberikan kepadanya sebesar Rp 20.000.000,- (dua puluh juta rupiah). Dr. Andika bertemu dengan saudara David dengan mengatakan bahwa pinjaman uang tersebut harus di aktakan di notaris dan pada tanggal 14 Agustus 2015 tepatnya hari jumat Drs. Andika dan David menemui Notaris Netty Maria Machdar.

Drs. Andika pergi bersama istri dan anak-anak ke kantor Notaris Netty Maria Machdar disana sudah ada David yang menunggu di ruang kantor notaris tersebut dan karyawan kantor notaris yang bernama Meidy keluar membawakan akta dan mengatakan ini akta pinjam meminjam dan disuruh mendandatangani dan David juga mengatakan bahwa itu hanya akta biasa dan tidak ada efek apa-apa terhadap tanah.

Drs. Andika menandatangani 2 (dua) akta dimana saat penandatanganan akta tersebut Notaris Netty Maria Machdar tidak membacakan isi dari akta tersebut melainkan sibuk membicarakan anak-anak dan bisnis lain dan setelah pulang dari kantor Notaris Netty Maria Machdar. Kemudian Drs. Andika berbicara dengan David bahwa pinjaman Rp 200.000.000,- (dua ratus juta rupiah) yang dijanjikan baru diterima $\mathrm{Rp} 37.000 .000$,- (tiga puluh tujuh juta rupiah) dan kemudian memberikan lagi sebesar Rp. 2.400.000,(Dua juta empat ratus rupiah) dan Rp 2.600.000,- (dua juta enam ratus rupiah) dengan biaya notaris yang dibebankan kepada Drs. Andika sehingga 
total menjadi Rp 42.000.000,- (empat puluh dua juta rupiah) dan sisanya dijanjikan esokan hari di transfer.

Pada hari Senin, 18 Agustus 2015 Andika berserta istri dan kakak mendatangi kantor Notaris Netty Maria Machdar untuk mempertanyakan akta apa yang sebenarnya Ia tandangtangani kemarin dan Netty Maria Machdar mengatakan bahwa akta tersebut adalah Perjanjian Pengikat Jual Beli (PPJB) dan Surat Kuasa Menjual dan kemudian Netty mengatakan bahwa Drs. Andika sudah tidak berhak lagi atas assetnya karena telah dijaminkan.

Drs. Andika merasa tertipu karena akta yang seharusnya akta pinjam meminjam bukan akta PPJB dan Kuasa Menjual dan Andika meminta kepada Ibu Netty untuk menghubungi david agar dibuatkan pembatalan akata ke 2 (dua) akta tersebut. Drs. Andika menerangkan bahwa ibu Netty tidak menjelaskan bahwa akta tersebut adalah PPJB dan Kuasa Menjual dan apabila telah menandatangani kedua akta tersebut maka hak atas tanah tersebut menjadi hilang dan Ibu Netty juga tidak memberikan 2 (dua) salinan akta yang telah di tanda tangani akan tetapi yang diberikan oleh Ibu Netty hanya David.

Dalam Surat Keterangan Nomor 04/Ket.Cuti-MPPN/II/2015 mengatakan bahwa ternyata Notaris Netty Maria Machdar dalam keadaan cuti setalah mengetahui akta-akta tersebut dan sertifikat cuti.

\section{B. Pemeriksaan di Majelis Pengawas Daerah (MPD) Jakarta Barat}

Drs. Andhika menjelaskan bahwa pihak Netty Maria Machdar dan David datang ke kantor Notaris dengan maksud membuatkan akta perjanjian dan Netty Maria Machdar beranggapan para pihak berteman baik jadi Netty Maria machdar percaya begitu saja tentang perjanjian yang dibuatnya.

Majelis Pengawas Daerah Notaris Kota Administrasi Jakarta Barat sudah melakukan sidang pada tanggal 7 Oktober 2015 yang dihadiri oleh Drs. Andika dan tidak dihadiri Netty Maria Machdar, sidang pada tanggal 4 
Desember 2015 yang dihadiri oleh Netty Maria Machdar dan sidang pada tanggal 13 Januari 2016 yang dihadiri oleh Drs. Andika.

Majelis Pengawas Daerah Notaris Kota Administrasi Jakarta Barat berkesimpulan bahwa Netty Maria Machdar dalam perbuatan Akta Pengikatan Jual Beli Nomor 14 tanggal 14 Agustus 2015 tentang Pengikatan Jual Beli dan Nomor 15 tanggal 14 Agustus 2015 tentang Kuasa Menjual masih dalam status cuti selama 1 (satu) tahun 6 (enam) bulan tanggal 2 Maret 2015 sampai dengan 2 September 2016 sebagaimana Surat keputusan Cuti dari Majelis Pengawas Pusat Notaris RI Nomor : 04/KET.CUTIMPPN/II/2015 tanggal 9 Maret 2015.

C. Hasil Putusan Majelis Pemeriksa Wilayah (MPW) Notaris Provinsi Daerah Khusus Ibukota Mengusulkan Kepada Majelis Pengawas Pusat (MPP)

1. Pengaduan Pelapor telah cukup bukti.

2. Terlapor telah melanggar Undang-Undang Nomor 2 Tahun 2014 tentang Perubahan Atas Undang-Undang Nomor 30 Tahun 2004 tentang Jabatan Notaris Pasal 16 ayat (1)

3. Mengusulkan Pemberhentian Sementara Netty Maria Machdar dari jabatannya sebagai Notaris selama 6 (enam) bulan.

\section{Kewajiban Notaris Dalam Mmebuat Akta}

Syarat-syarat pembuatan akta menurut Undang-Undang Nomor 2 Tahun 2014 tentang Jabatan Notaris terdapat pada Pasal 38 ${ }^{26}$ :

1. Setiap Akta terdiri atas:
a. Awal akta atau kepala akta;
b. Badan akta; dan
c. Akhir atau penutup akta.

26) Indonesia, Undang-Undang Nomor 2 Tahun 2014 tentang Jabatan Notaris, hal. 10. 
2. Akta atau kepala akta memuat:
a. Judul akta;
b. Nomor akta;
c. Jam, hari, tanggal, bulan, dan tahun; dan
d. Nama lengkap dan tempat kedudukan notaris.

3. Badan akta memuat:

a. Nama lengkap, tempat dan tanggal lahir, kewarganegaraan, pekerjaan, jabatan, kedudukan, tempat tinggal para penghadap dan/atau orang yang mereka wakili;

b. Keterangan mengenai kedudukan bertindak penghadap;

c. Isi akta yang merupakan kehendak dan keinginan dari pihak yang berkepentingan; dan

d. Nama lengkap, tempat dan tanggal lahir, serta pekerjaan, jabatan, kedudukan, dan tempat tinggal dari tiap-tiap saksi pengenal.

4. Akhir atau penutup akta memuat:

a. Uraian tentang pembacaan akta sebagaimana dimaksud dalam Pasal 16 ayat (1) huruf $m$ atau pasal 16 ayat (7);

b. Uraian tentang penandatanganan dan tempat penandatanganan atau penerjemahan akta jika ada;

c. Nama lengkap, tempat dan tanggal lahir, pekerjaan, jabatan, kedudukan, dan tempat tinggal dari tiap-tiap saksi akta; dan

d. Uraian tentang tidak adanya perubahan yang terjadi dalam pembuatan akta atau uraian tentang adanya perubahan yang dapat berupa penambahan, pencoretan, atau penggantian serta jumlah perubahannya.

5. Akta notaris pengganti dan pejabat sementara notaris, selain memuat ketentuan sebagaimana dimaksud pada ayat (2), ayat (3), dan ayat (4), juga memuat nomor dan tanggal penetapan pengangkatan serta pejabat yang mengangkatnya. 
Menurut Undang-Undang Nomor 2 tahun 2014 tentang Jabatan Notaris pada pasal 40 dijelaskan sebagai berikut ${ }^{27}$ :

1. Setiap akta yang dibacakan oleh notaris dihadiri paling sedikit 2 (dua) orang saksi, kecuali peraturan perundang-undangan menentukan lain.

2. Saksi sebagaimana dimaksud pada ayat (1) harus memenuhi syarat sebagai berikut:

a. Paling rendah berumur 18 (delapan belas) tahun atau sebelumnya telah menikah;

b. Cakap melakukan perbuatan hukum;

c. Mengerti bahasa yang digunakan dalam akta;

d. Dapat membubuhkan tanda tangan dan para, dan

e. Tidak mempunyai hubungan perkawinan atau hubungan darah dalam garis lurus ke atas atau ke bawah tanpa pembatasan derajat dan garis ke samping sampai dengan derajat ketiga dengan notaris atau para pihak.

3. Saksi sebagaimana dimaksud pada ayat (1) harus dikenal oleh notaris atau diperkenalkan kepada notaris atau diterangkan tentang identitas dan kewenangannya kepada notaris oleh penghadap.

4. Pengenalan atau pernyataan tentang identitas dan kewenangan saksi dinyatakan secara tegas dalam akta

Pada Pasal 43 Undang-Undang Nomor 2 Tahun 2014 tentang Jabatan Notaris adalah:

1. Akta wajib dibuat dalam bahasa Indonesia.

2. Dalam hal penghadap tidak mengerti bahasa yang digunakan dalam akta, notaris wajib menerjemahkan atau menjelaskan isi akta itu dalam bahasa yang dimengerti oleh penghadap.

3. Jika para pihak menghendaki, akta dapat dibuat dalam bahasa asing.

4. Dalam hal akta dibuat sebagaimana dimaksud pada ayat (3), notaris wajib menerjemahkannya ke dalam bahasa Indonesia.

\footnotetext{
${ }^{27)}$ Indonesia, Undang-Undang Nomor 2 Tahun 2014 tentang Jabatan Notaris, hal. 11.
} 
5. Apabila notaris tidak dapat menerjemahkan atau menjelaskannya, akta tersebut diterjemahkan atau dijelaskan oleh seorang penerjemah resmi.

6. Dalam hal terdapat perbedaan penafsiran terhadap isi akta sebagaimana dimaksud pada ayat (2), maka yang digunakan adalah akta yang dibuat dalam bahasa Indonesia.

Menurut Pasal 44 Undang- Undang Nomor 2 Tahun 2014 tentang Jabatan Notaris dijelaskan:

1. Segera setelah akta dibacakan, akta tersebut ditandatangani oleh setiap penghadap, saksi, dan notaris, kecuali apabila ada penghadap yang tidak dapat membutuhkan tanda tangan dengan menyebutkan alasannya.

2. Alasan sebagaimana dimaksud pada ayat (1) dinyatakan secara tegas pada akhir akta.

3. Akta sebagaimana dimaksud dalam pasal 43 ayat (3) ditandatangani oleh penghadap, notaris, saksi, dan penerjemah resmi.

4. Pembacaan, penerjemahan atau penjelasan dan penandatanganan sebagaimana dimaksud pada ayat (1) dan ayat (3) serta dalam pasal 43 ayat (3) dinyatakan secara tegas pada akhir akta.

5. Pelanggaran terhdap ketentuan sebagaimana dimaksud pada ayat (1), ayat (2), ayat (3), dan ayat (4) mengakibatkan suatu akta hanya mempunyai kekuatan pembuktian sebagai akta di bawah tangan dan dapat menjadi alasan bagi pihak yang menderita kerugian untuk menuntut penggantian biaya, ganti rugi, dan bunga kepada notaris.

Menurut Undang-Undang Nomor 2 Tahun 2014 pada Pasal 48 juga dijelaskan larangan dalam membuat akta sebagai berikut:

1. Isi akta dilarang untuk diubah dengan:
a. Diganti;
b. Ditambah;
c. Dicoret;
d. Disisipkan;
e. Dihapus; dan/atau
f. Ditulis tindih. 
2. Perubahan isi akata sebagaimana dimaksud pada ayat (1) huruf a, huruf b, huruf c, dan huruf d dapat dilakukan dan sah jika perubahan tersebut diparaf atau diberi tanda pengesahan lain oleh penghadap, saksi, dan Notaris.

3. Pelanggaran terhadap ketentuan sebagaimana dimaksud pada ayat (1) dan ayat (2) mengakibatkan suatu akta hanya mempunyai kekuatan pembuktian sebagai akta di bawah tangan dan dapat menjadi alasan bagi pihak yang menderita kerugian untuk menuntut penggantian biaya, ganti rugi, dan bunga kepada notaris

Ketentuan-ketentuan dalam perubahan akta diatur dalam Pasal 49 Undang-Undang Nomor 2 Tahun 2014 tentang Jabatan Notaris yang berisikan sebagai berikut:

1. Setiap perubahan atas akta sebagaimana dimaksud dalam pasal 48 ayat (2) dibuat di sisi kiri akta.

2. Dalam hal suatu perubahan tidak dapat dibuat di sisi kiri akta, perubahan tersebut dibuat pada akahir akta, sebelum penutup akta, dengan menunjuk bagian yang diubah atau dengan menyisipkan lembar tambahan.

3. Perubahan yang dilakukan tanpa menunjukan bagian yang diubah mengakibatkan perubahan tersebut batal.

4. Pelanggaran terhadap ketentuan sebagaimana dimaksud pada ayat (1) dan ayat (2) mengakibatkan suatu akta hanya mempunyai kekuatan pembuktian sebagai akta dibawah tangan dan dapat menjadi alasan bagi pihak yang menderita kerugian untuk menuntut penggantian biaya, ganti rugi, dan bunga kepada notaris.

Dalam Pasal 50 Undang-Undang Nomor 2 tahun 2014 tentang Jabatan Notaris dijelaskan tentang ketentuan pencoretan dalam akta yang dijelaskan sebagai berikut:

1. Jika dalam akta perlu dilakukan pencoretan kata, huruf, atau angka, pencoretan dilakukan sedemikian rupa sehinga tetap dapat dibaca sesuai 
dengan yang tercantum semula, dan jumlah kata, huruf, atau angka yang dicoret dinyatakan pada sisi kiri akta.

2. Pencoretan sebagaimana dimaksud pada ayat (1) dinyatakan sah setalah diparaf atau diberi tanda pengesahan lain oleh penghadap, saksi, dan notaris

3. Dalam hal terjadi perubahan lain terhadap pencoretan sebagaimana dimaksud pada ayat (2), perubahan itu dilakukan pada sisi kiri akta sesuai dengan ketentuan sebagaimana dimaksud dalam pasal 49 ayat (2).

4. Pada penutup setiap akta dinyatakan tentang ada atau tidak adanya perubahan atas pencoretan

5. Dalam hal ketentuan sebagaimana dimaksud pada ayat (1), ayat (2), ayat (3), dan ayat (4), serta dalam pasal 38 ayat (4) huruf d tidak dipenuhi, akta tersebut hanya mempunyai kekeuatan pembuktian sebagai akta di bawah tangan dan dapat menjadi alasan bagi pihak yang menderita kerugian untuk menuntut penggantian biaya, ganti rugi, dan bunga kepada notaris.

Pada Pasal 51 Undang-Undang Nomor 2 Tahun 2014 diatur juga sebagai berikut:

1. Notaris berwenang untuk membetulkan kesalahan tulis dan/atau kesalahan ketik yang terdapat pada minuta akta yang telah ditandatangani.

2. Pembetulan sebagaimana dimaksud pada ayat (1) dilakukan di hadapan penghadap, saksi dan notaris yang dituangkn dalam berita acara dan memberikan catatan tentang hal tersebut pada minuta akta asli dengan menyebutkan tanggal dan nomor akta berita acara pembetulan.

3. Salinan akta berita acara sebagaimana dimaksud dalam ayat (2) wajib disampaikan kepada para pihak.

4. Pelanggaran terhadap ketentuan sebagaimana dimaksud dalam ayat (2) mengakibatkan suatu akta hanya mempunyai kekuatan pembuktian sebagai akat dibawah tangan dan dapat menjadi alasan bagi pihak yang 
menderita kerugian untuk menuntut penggantian biaya, ganti rugi, dan bunga kepada notaris.

Larangan notaris dalam membuat akta yang terdapat pada Pasal 54 Undang-Undang Nomor 2 Tahun 2014 tentang Jabatan Notaris yang berisi sebagai berikut:

1. Notaris hanya dapat memberikan, memperlihatkan, atau memberitahukan isi akta, grosse akta, salinan akta atau kutipan akta, kepada orang yang berkepentingan lagsung pada akta, ahli waris, atau orang yang memperoleh hak, kecuali ditentukan lain oleh peraturan perundangundangan

2. Notaris yang melanggar ketentuan sebagaimana dimaksud pada ayat (1) dapat dikenai sanksi berupa:

a. Peringatan tertulis;

b. Pemberhentian sementara;

c. Pemeberhentian dengan terhormat; atau

d. Pemberhentian dengan tidak hormat.

Sesuai dengan uraian diatas kewajiban notaris dalam membuat akta adalah seorang notaris wajib menjalankan tugasnya dalam pembuatan akta sesuai dengan Undang-Undang Nomor 2 tahun 2014 tentang Perubahan Atas Undang-Undang Nomor 3 Tahun 2004 tentang Jabatan Notaris. Dalam Undang-Undang tercantum syarat-syarat pembuatan akta yang harus dipenuhi oleh notaris. Apabila notaris melakukan kesalahan dalam kewajibannya dalam membuat akta maka akan mendapatkan sanksi hukum sesuai dengan Undang-Undang.

\section{E. Akta yang dibuat Notaris Netty Maria Machdar dalam perikatan antara Drs. Andhika dan David}

1. Fakta Hukum bersumber dari Studi Kasus Putusan Nomor: 1/PTS/Mj.PWN.Prov.DKIJakarta/XI/2017

a. Drs. Andhika merasa dirugikan karena terbitnya Akta Pengikat Jual Beli Nomor 14 tanggal 14 Agustus 2015 tentang Pengikatan Jual 
Beli dan Nomor 15 tanggal 14 Agustus 2015 tentang Kuasa Menjual yang dibuat oleh Netty Maria Machdar

b. Drs. Andika mendalilkan dalam pengaduannya bahwa Netty Maris Machdar telah melanggar Undang-Undang Nomor 30 Tahun 2004 tentang Jabatan Notaris juncto Undang-Undang Nomor 2 Tahun 2014 tentang Jabatan Notaris maka yang demikian bisa mendapatkan sanksi sesuai hukum yang berlaku

c. Drs. Andhika dapat membuktikan dalil Netty Maria Machdar

d. Berdasarkan Surat Keputusan Cuti dari Majelis Pengawas Pusat Notaris RI Nomor : 04/KET.CUTI-MPPN/II/2015 tanggal 9 Maret 2015 tentang cuti Netty Maria Machdar selama 1 (satu) tahun 6 (enam) bulan tanggal 2 Maret 2015 sampai dengan 2 September 2016 sehingga Netty Maria Machdar dalam keadaan cuti tidak berwenang membuat Akta Otentik

e. Pengaduan yang diajukan oleh Drs. Andhika sudah sesuai dengan Peraturan Menteri Hukum dan Hak Asasi Manusia Nomor : M.02.PR.08.10 Tahun 2004

f. Pihak Netty Maria Machdar telah diperiksa oleh Majelis Pengawas Daerah Notaris Kota Administrasi Jakarta Utara dan dituangkan dalam surat Majelis Pengawas Daerag Notaris Kota Administrasi Jakarta Barat Nomor : 1/BAP/LAPMAS/2016

g. Hasil sidang Majelis Pemeriksa Wilayah Notaris Provinsi DKI Jakarta pada haris selasa, tanggal 16 Maret 2017 yang sudah kuorum karena dihadiri oleh tiga undur anggota Majelis Pemeriksa Wilayah Notaris Provinsi DKI Jakarta

2. Cuti

Netty Maria Machdar sudah jelas melanggar peraturan UndangUndang Nomor 2 Tahun 2014 tentang Jabatan Notaris karena adanya Surat Keputusan Cuti dari Majelis Pengawas Pusat Notaris RI Nomor : 04/KET.CUTI-MPPN/II/2015 tanggal 9 Maret 2015 tentang cuti Netty 
Maria Machdar selama 1 (satu) tahun 6 (enam) bulan tanggal 2 Maret 2015 sampai dengan 2 September 2016.

Dengan demikian apabila seorang notaris sedang mengambil cuti maka Notaris tersebut sudah tidak mempunyai wewenangan dalam membuat akta otentik karena adanya notaris pengganti yang sudah di tunjuk dam disumpah untuk menggantikan posisi notaris utama dalam melakukan wewenang tersebut.

Hal ini juga telah di atur dalam Undang-Undang Nomor 2 Tahun 2014 tentang Jabatan Notaris yang terdapat pada Pasal 32 dinyatakan bahwa $^{28}$ :

1. Notaris yang menjalankan cuti wajib menyerahkan Protokol Notaris kepada Notaris Pengganti;

2. Notaris Pengganti menyerahkan kembali Protokol Notaris setelah cuti berakhir;

3. Serah terima sebagaimana dimaksud pada ayat (1) dan ayat (2) dibuatkan berita acara dan disampaikan kepada Majelis Pengawas Wilayah;

4. Notaris yang melanggar ketentuan sebagaimana dimaksud pada ayat (1), ayat (2), dan ayat (3) dapat dikenai sanksi berupa:

a. Peringatan Tertulis;

b. Pemberhentian sementara

c. Pemberhentian dengan hormat; atau

d. Pemberhentian dengan tidak hormat.

Adanya aturan ini sudah jelas dan wajib di patuhi sehingga dengan kata lain Notaris Netty Maria Machdar sudah jelas melanggar peraturan yang berlaku dan telah merugikan orang lain. Dan sudah jelas dengan adanya surat keterangan cuti yang di keluarkan oleh Majelis Pengawas Pusat membuat Netty Maria Machdar tidak berwenang membuat akta otentik.

${ }^{28)}$ Indonesia, Undang-undang Nomor 2 Tahun 2014 tentang Jabatan Notaris, Pasal 32 


\section{F. Pertanggungjawaban Notaris Netty Maria Machdar}

Menurut Raden Soegondo Notodisoerjo menyatakan tentang apa yang dapat dipertanggungjawabankan oleh notaris yaitu apabila penipuan atau tipu muslihat itu bersumber dari notaris sendiri. Hal tersebut dapat terjadi apabila seorang notaris dalam suatu transaksi peralihan hak misalnya dalam akta jual beli sengaja mencantumkan harga lebih rendah dari harga yang sesngguhnya. ${ }^{29}$

Pertangganggungjawaban yang dapat dilakukan Netty Maria Machdar apabila dilihat dari Undang-Undang dapat berupa :

1. Peringatan tertulis;

2. Pemberhentian sementara;

3. Pemberhentian dengan hormat; dan/atau

4. Pemberhentian dengan tidak hormat

Tetapi dalam kasus Netty Maria Machdar tidak hanya diberlakukan pemberhentian tetap melainkan juga harus adanya ganti kerugian yang di timbulkan karena adanya orang di rugikan.

Hal ini dapat terjadi karena apabila dilihat dari kasus Netty Maria Machdar yang terbukti bersalah dengan membuat kesalahan dalam pembuatan akta yang awalnya diminta untuk dibuatkan akta pinjam meminjam malah dibuatkan akta surat kuasa jual yang menimbulkan kerugian bagi kliennya.

Diketahui pula akta yang dibuat oleh Netty Maria Machar dikeluarkan pada saat ia sedang melakukan cuti. Hal ini diketahui karena adanya surat keterangan cuti dari Majelis Pengawas Pusat Notaris RI Nomor : 04/KET.CUTI-MPPN/II/2015. Sehingga dalam hal ini Netty Maria Machdar melakukan kesalahan besar yang sangat merugikan kliennya karena seorang notaris tidak dapat membuat akta otentik dalam keadaan cuti.

\footnotetext{
${ }^{29)}$ Raden Soegondo notodisoerjo, Hukum Notariat di Indonesia Suatu Penjelasan Cetakan kedua, (Jakarta: Raja Grafindo Persada, 1993), hal. 229.
} 
Hal ini telah di atur dalam Undang-Undang Nomor 2 Tahun 2014 tentang Jabatan Notaris Pasal 32 yang mengatakan bahwa ${ }^{30}$ :

1. Notaris yang menjalankan cuti wajib menyerahkan Protokol Notaris kepada Notaris Pengganti.

2. Notaris Pengganti menyerahkan kembali Protokol Notaris setelah cuti berakhir.

3. Serah terima sebagaimana dimaksud pada ayat (1) dan ayat (2) dibuatkan berita acara dan disampaikan kepada Majelis Pengawas Wilayah.

4. Notaris yang melanggar ketentuan sebagaimana dimaksud pada ayat (1), ayat (2), dan ayat (3) dapat dikenai sanksi berupa:

a. Peringatan tertulis;

b. Pemberhentian sementara;

c. Pemberhentian dengan hormat; atau

d. Pemberhentian dengan tidak hormat.

Sehingga dalam hal ini karena sudah adanya Undang-Undang Nomor 2 Tahun 2014 tentang Jabatan Notaris yang mengatur aturan dan sanksi yang diberikan kepada notaris apabila melanggar maka notaris tersebut dapat dikenakan sanksi. Notaris Netty Maria Machdar mendapatkan sanksi berupa pemberhentian sementara masa jabatan dan dapat dikenakan sanksi berupa ganti rugi.

Menurut keputusan Majelas Pemeriksa Wilayah Notaris Provinsi Daerah Khusus Ibukota Tentang Laporan Pengaduan Masyarakat atas Nama Drs. Andhika yang telah mempunyai cukup bukti bahwa Netty Maria Machdar diusulkan untuk diberhentikan sementara dari jabatannya sebagai notaris selama 6 (enam) bulan. Sebagai pertanggungjawaban atas perbuatannya yang telah terbukti bersalah karena dianggap telah merugikan Drs. Andhika.

\section{PENUTUP}

Berdasarkan Pokok Permasalahan yang digunakan, maka dapat disampaikan suatu kesimpulan dan saran sebagai berikut :

30) Indonesia, Undang-undang Nomor 2 Tahun 2014 tentang Jabatan Notaris, Pasal 32. 


\section{A. Kesimpulan}

Berdasarkan pembahasan penelitian yang diuraikan ini, maka penulis dapat menarik kesimpulan bahwa Notaris Netty Maria Machdar terbukti bersalah karena telah merugikan Drs. Andhika dengan salah membuat akta yang seharusnya adalah Akta Pinjam Meminjam menjadi Akta Surat Kuasa Menjual sehingga merugikan kliennya karena Drs. Andika yang kehilangan asset yang dimilikinya yang berupa rumah di Depok dengan Sertifikat Hak Milik Nomor 11136

Menurut bukti-bukti yang ada Akta Otentik tersebut dibuat oleh Netty Maria Machdar pada saat menjalankan masa cuti yang terdapat pada Surat Keputusan Cuti dari Majelis Pengawas Pusat Notaris RI Nomor : 04/KET.CUTI-MPPN/II/2015 tanggal 9 Maret 2015 tentang cuti Netty Maria Machdar selama 1 (satu) tahun 6 (enam) bulan tanggal 2 Maret 2015 sampai dengan 2 September 2016 sehingga Netty Maria Machdar dalam keadaan cuti tidak berwenang membuat Akta Otentik. Netty Maria Machdar terbukti membuat 146 Akta Otentik selama masa cutinya. Hal ini tebukti dari adanya pemeriksaan yang dilakukan oleh Majelis Pengawas Wilayah DKI Jakarta.

Akta Otentik yang telah dibuatnya pada masa cuti menjadi Akta di Bawah Tangan hal ini disebabkan karena akta-akta yang telah dibuat pada masa cuti tidak dapat disebut Akta Otentik lagi karena hilangnya kekuatan otentiksitasnya yang di sebabkan oleh notaris tersebut sehingga akta tersebut tidak menjadi sah dan menjadi Akta di Bawah Tangan.

\section{B. Saran}

1. Meningkatan mutu kualitas profesi notaris sehingga dalam penyeleksian atau penyaringan profesi harus lebih di perketat dan lebih jelas lagi syarat dan ketentuannya. Agar terhindar dari adanya notaris bandel.

2. Meningkatkan peranan Majelis Pengawas Daerah (MPD), Majelis Pengawas Wilayah (MPW), Majelis Pengawas Pusat (MPP) dan Ikatan Notaris Indonesia (INI) dalam pelaksanaan pengawasan notaris agar meminimalisirkan notaris yang melanggar. 


\section{DAFTAR PUSTAKA}

\section{A. BUKU}

Adji,Habib. Sekilas Dunia Notaris \& PPAT Indonesia (Kumpulan Tulisan). (Bandung: Mandar Maju, 2009).

Asshiddiqie,Jimly. Etik dan Etika Konstitusi Perspektif Baru Tentang ('Rule of Law and Rule of Ethics' \& Constitutional Law and Constitutional Ethics') edisi revisi. (Jakarta: Sinar Grafika, 2016).

Fajar,Mukti. dan Achmad Yulianto. Dualisme Penelitian Hukum Normatif dan Empiris. (Yogyakarta: Pustaka Pelaja, 2010).

Kusumaatmaja,Mochtar. dan, Sidharta Arief. Pengantar Ilmu Hukum Suatu Pengenalan Pertama Ruang Lingkup Berlakunya Ilmu Hukum Buku I. (Bandung: Alumni, 2000).

Marzuki,Mahmud,Peter. Penelitian Hukum Cetakan ke-11. (Jakarta: Kencana, 2011).

Notodisoerjo,Soegondo,Raden. Hukum Notariat di Indonesia Suatu Penjelasan Cetakan kedua. (Jakarta: Raja Grafindo Persada, 1993).

Pengurus Pusat Ikatan Notaris Indonesia. Jati Diri Notaris Indonesia, Dulu, Sekarang dan di Masa Datang. (Jakarta: PT. Gramedia Pustaka, 2008).

Soemoatmodjo, Soetardjo. Apakah: Notaris, Pejabat Pembuat Akta Tanah dan Pejabat Lelang. (Yogyakarta: Liberty, 1986).

\section{B. PERATURAN PERUNDANG-UNDANGAN}

Indonesia. Undang-undang Nomor 2 Tahun 2014 tentang Jabatan Notaris (Lembaran Negara Republik Indonesia Tahun 2014 Nomor 3, Tambahan Lembaran Negara Republik Indonesia Nomor 5491).

\section{Website}

Faraytody, Leo. "Memahami Pentingnya Jasa Notaris Dan PPAT Dalam Bisnis", https://easybiz.id/memahami-pentingnya-jasa-notaris-dan-ppatdalam bisnis/, 2018 